\title{
FOUNDATION - CASE Tools for the Success of the French Stock Exchange
}

\author{
Filippo De Capua \\ (Invited speaker) \\ SICOVAM, 5 Rue du Centre \\ 93167 Noisy le Grand, France
}

\begin{abstract}
When the French Stock Exchange decided to renovate its procedures and systems, in order to compete with the biggest worldwide exchanges, a large project was set up. Numerous participants were involved in the project (banks, brokers, service providers, vendors, ...).

The presentation will show how the use of FOUNDATION helped deliver a quality system within deadlines and budget. It will present measurements of that quality. It will also explain how FOUNDATION helped SICOVAM maintain quality and control of its developments during its growth from a 2 Mips site to an 80 Mips site. The presentation will also summarize some of the issues implementing CASE in the development system's and production groups.
\end{abstract}

Filippo De Capua is DP Manager (Directeur Informatique) of SICOVAM (Société Interprofessionnelle de Compensation des Valeurs Mobilières). SICOVAM manages the central database of the French Stock Market. It is a company of 350 people. The Data Processing Department represents 100 people, plus an important number of subcontractors. Filippo De Capua joined SICOVAM in 1988 to manage the rapid growth of the DP Department (now 2 3090-200) and the implementation of the brand new back office system of the French Bourse (RELIT). 